\title{
Is late thrombolysis effective for subacute renal vein thrombosis in patients with nephrotic syndrome? a case report
}

\section{É efetiva a trombólise para trombose venosa renal subaguda em pacientes com síndrome nefrótica? um relato de caso}

Johann Vargas Silva ${ }^{1}$. Elizabeth de Francesco Daher ${ }^{1,2}$. Pastora Maria Araújo Duarte ${ }^{1}$. Frederico Augusto de Carvalho Linhares Filhoํ․ Victor Cordero Zarate Júnior ${ }^{1}$. Sônia Leite da Silva ${ }^{1}$.

1 Hospital Universitário Walter Cantídio (HUWC), Universidade Federal do Ceará (UFC), Fortaleza, Ceará, Brasil. 2 Hospital Geral de Fortaleza (HGF), Fortaleza, Ceará, Brazil.

\section{ABSTRACT}

Renal vein thrombosis (RVT) associated with nephrotic syndrome (NS) in patients with flank pain is rarely the earliest manifestation. Despite the absence of formal guidelines, treatment generally consists of prophylaxis against new thrombotic events and clot dissolution (thrombolysis) or clot removal (thrombectomy). We describe the case of a 25-year-old woman with lumbar pain, nausea and vomiting, who developed nephrotic proteinuria, macroscopic hematuria and loss of renal function requiring hemodialysis without improvement with methylprednisolone and cyclophosphamide. Considered diagnoses of systemic lupus erythematosus (SLE) and antiphospholipid antibody syndrome (APS). Angiotomography showed subacute vena cava thrombosis with extension to the two renal veins. Alteplase thrombolysis was performed to recovery of renal function. Patient progressed with improvement of renal function and discontinuation of hemodialysis. In conclusion, late thrombolysis may be effective for subacute RVT in NS patients.

Keywords: Nephrotic syndrome. Lupus erythematosus, systemic. Antiphospholipid syndrome. Acute kidney injury. Venous thrombosis. Thrombolytic therapy.

\section{RESUMO}

A trombose venosa renal (RVT) associada à síndrome nefrótica (SN) em pacientes com dor no flanco raramente é a manifestação mais precoce. Apesar da ausência de diretrizes formais, o tratamento geralmente consiste em profilaxia contra novos eventos trombóticos e dissolução do coágulo (trombólise) ou remoção do coágulo (trombectomia). Descrevemos o caso de uma mulher de 25 anos com dor lombar, náusea e vômito, que desenvolveu proteinúria nefrótica, hematúria macroscópica e perda da função renal, necessitando de hemodiálise sem melhora com metilprednisolona e ciclofosfamida. Considerados diagnósticos de lúpus eritematoso sistêmico (LES) e síndrome do anticorpo antifosfolípide (SAF). A angiotomografia mostrou trombose da veia cava subaguda com extensão para as duas veias renais. A trombólise com alteplase foi realizada para recuperação da função renal. O paciente evoluiu com melhora da função renal e descontinuação da hemodiálise. Em conclusão, a trombólise tardia pode ser eficaz para a RVT subaguda em pacientes com SN.

Palavras-chave: Síndrome nefrótica. Lúpus eritematoso sistêmico. Síndrome antifosfolípide. Lesão renal aguda. Trombose venosa. Terapia trombolítica.

Corresponding author: Johann Vargas Silva, Rua das Carnaúbas, 371, Passaré, Fortaleza. CEP: 60743-780. Telefone: +55 85 99994-6424. E-mail: drvargasufc@yahoo.com.br

Conflict of interests: The authors have no conflicts of interest to declare.

Received: 19 Nov 2018; Revised: 09 Oct 2019; Accepted: 12 Nov 2019. 


\section{INTRODUCTION}

Patients with nephrotic syndrome (NS) are at increased risk of vascular thrombosis, especially deep vein thrombosis and renal vein thrombosis (RVT). ${ }^{1-2}$ In addition, pulmonary embolism, cerebral venous sinus thrombosis and arterial thrombosis are more frequent in NS patients than in the general population..$^{2-5}$ RVT is the formation of a clot in the renal vein or its main branches. ${ }^{6}$ It may occur at any age, including in fetus and newborns. In children and adults it is often associated with NS. Men are more frequently affected than women, regardless of ethnicity. In two thirds of cases, RVT is bilateral. When unilateral, it mostly affects the left renal vein. RVT may resolve spontaneously or develop into hypertension and acute renal failure. ${ }^{6}$ Treatment includes prevention of new thrombotic events and thrombolysis or thrombectomy. However, no standard guidelines exist regarding indications for thrombolysis/thrombectomy. The purpose of this paper is to describe an NS patient with subacute bilateral RVT and acute kidney injury responding to late thrombolysis with stabilization of kidney function, and to discuss the mechanism of acute renal injury in this scenario.

\section{CASE REPORT}

Three weeks before admission to our service (Hospital Universitário Walter Cantídio, Fortaleza, Brazil), MGP, a 25-year old Caucasian female, experienced sudden and persistent low back pain irradiating to the left iliac fossa. Initially mild, the pain worsened progressively and was accompanied by nausea, vomiting and oliguria, with no fever or clinically detectable cause. Upon the first consultation, the patient was prescribed anti-inflammatory drugs (NSAIDs) for unspecific low back pain. On abdominal and pelvic $\mathrm{CT}$, a renal inflammatory process was observed on the left side, compatible with pyelonephritis and pleuropulmonary involvement.

Two weeks before admission, the patient was treated at another facility for fever without shivering, dark and foamy urine and lower limb edema. The laboratory findings included hemoglobin $10.9 \mathrm{~g} / \mathrm{dL}$, leukocytes $17,970 / \mathrm{mm}^{3}$ (rods $2 \%$, segmented $86.5 \%$, lymphocytes $9.7 \%$, monocytes $5.3 \%$, eosinophils $1.4 \%$ ), platelets $130,000 / \mathrm{mm}^{3}$, serum creatinine $0.9 \mathrm{mg} / \mathrm{dL}$ (0.6-1.1), urea $27 \mathrm{mg} / \mathrm{dL}$ (10-50), urine protein 3+, hemoglobin $3+$, and numerous red blood cells on sediment microscopy. The patient was started on ceftriaxone, followed by partial improvement of symptoms.

The patient presented low back pain and vomiting at admission. The medical history included hepatitis at age 8, fetal loss (eclampsia) 3 years previously, and episodes of distal interphalangeal arthritis, alopecia and maculopapular rash responsive to corticoid treatment. The patient was taking captopril at $25 \mathrm{mg} /$ day for post-eclampsia hypertension.

Upon physical examination, the patient's condition was good overall (axillary temperature $36^{\circ} \mathrm{C}$, pulse $88 \mathrm{bpm}$, respiratory rate $20 \mathrm{bpm}$, arterial pressure 140/90 $\mathrm{mmHg}$, cutaneous- mucosal pallor, pansystolicmumur $(2+/ 6+)$, flaccid abdomen, mild pain in the left flank, and lower limb edema $(2+/ 4+)$. The blood test revealed hemoglobin $8.29 \mathrm{~g} / \mathrm{dL}$, hematocrits $26.1 \%$, leukocytes $7,960 / \mathrm{mm}^{3}$ (rods $3 \%$, neutrophils $81 \%$, monocytes $4 \%$, eosinophils $1 \%$, lymphocytes $13 \%$ ), platelets $116,000 / \mathrm{mm}^{3}$, serum creatinine $0.9 \mathrm{mg} / \mathrm{dL}(10-40)$, urea 23 $\mathrm{mg} / \mathrm{dL}$ (10-50), D-lactate dehydrogenase 792 IU/L (230460), alkaline phosphatase $260 \mathrm{IU} / \mathrm{L}$ (64-300), AST $21 \mathrm{IU} / \mathrm{L}$ $(<32)$, ALT $13 \mathrm{IU} / \mathrm{L}(<31), \gamma$-glutamyltransferase $116 \mathrm{IU} / \mathrm{L}$ (7-32), total bilirubin $0.23 \mathrm{mg} / \mathrm{dL}(<1)$, C-reactive protein 8.92 (negative), INR $1.09(<1.2)$, aPTT $125.8 \mathrm{~s}(<28.6)$, direct Coombs positivity, complement component 3 of $83 \mathrm{mg} / \mathrm{dL}$ (90-180), complement component 4 of $22 \mathrm{mg} / \mathrm{dL}$ (10-40), ANF positivity 1:640 (speckled pattern), and anti-DNA positivity. The findings of the urine analysis included urine density 1010 , $\mathrm{pH} 6.0$, protein $1+$, red blood cells per field 15 , leukocytes per field 6, proteinuria 3,639 mg/24h (30-140). Findings were normal for fibrinogen, electrolytes, glucose, amylase and lipase, and the serum was negative for syphilis, hepatitis B, hepatitis $\mathrm{C}$ and HIV. The patient was diagnosed with systemic lupus erythematosus (SLE).

The condition worsened, with progressive edema, hematuria and loss of renal function requiring dialysis. At this point, laboratory findings included hemoglobin $6.29 \mathrm{~g} / \mathrm{dL}$, hematocrits $19.3 \%$, leukocytes $5,560 / \mathrm{mm}^{3}$, platelets $87,600 /$ $\mathrm{mm}^{3}$, reticulocytes $1.48 \%$, haptoglobin $237 \mathrm{mg} / \mathrm{dL}$ (30-200), total bilirubin $0.26 \mathrm{mg} / \mathrm{dL}(<1)$, D-lactate dehydrogenase $687 \mathrm{~g} / \mathrm{dL}$ (230-460), direct Coombs positivity, fibrinogen $235 \mathrm{mg} / \mathrm{dL}$ (180-350), creatinine kinase $9 \mathrm{mg} / \mathrm{dL}(<170)$, albumin $2.3 \mathrm{~g} / \mathrm{dL}(3.5-4.8)$, free $\mathrm{T} 40.96 \mathrm{ng} / \mathrm{dL}(0.89$ 1.76), TSH $3.84 \mathrm{U} / \mathrm{mL}(0.4-4.0)$, total cholesterol $227 \mathrm{mg} /$ dL $(<200)$, HDL $33 \mathrm{mg} / \mathrm{dL}(40-85)$, triglycerides $384 \mathrm{mg} /$ $\mathrm{dL}(<150)$, prothrombin time $15.8 \mathrm{~s}(11.5 \mathrm{~s})$, INR 1.38 $(<1.2)$, aPTT $59.8 \mathrm{~s}(<28.6)$. Mixing patient plasma with normal plasma failed to correct the deficiency. Renal US revealed bilateral renal parenchymal echogenicity and perirenal fluid collection on the left side. The patient was treated with methylprednisolone pulse therapy ( $1 \mathrm{~g} /$ day) for three days, followed by cyclophosphamide (900 mg), with no improvement of renal function. On Doppler US of the renal arteries and veins, a 4.8-cm clot was seen in the inferior vena cava, with laminar flow and extension towards the right renal vein (not photographed). On angiotomography, a $7.6-\mathrm{cm}$ clot was seen in the inferior vena cava, extending towards both renal veins, from the retro-hepatic part to a point $7.7 \mathrm{~cm}$ from the bifurcation of the common iliac veins. These areas did not capture the endovenous contrast and may correspond to tissues with ischemia/infarction in the right kidney, without renal artery thrombosis (Figures 1 and 2). The patient tested negative for anticardiolipin ( $\mathrm{IgM}$ and $\mathrm{IgG}$ ) and anti-beta2-glycoprotein $\mathrm{I}(\mathrm{IgM})$ antibody, but positive for lupus anticoagulant. This was considered a diagnostic confirmation of antiphospholipid antibody syndrome (APS) secondary to SLE. Renal biopsy was not performed due to the risk of bleeding associated with thrombocytopenia and unfractionated heparin-induced anticoagulation. 
Figure 1. Inferior vena cava thrombosis e bilateral RVT.

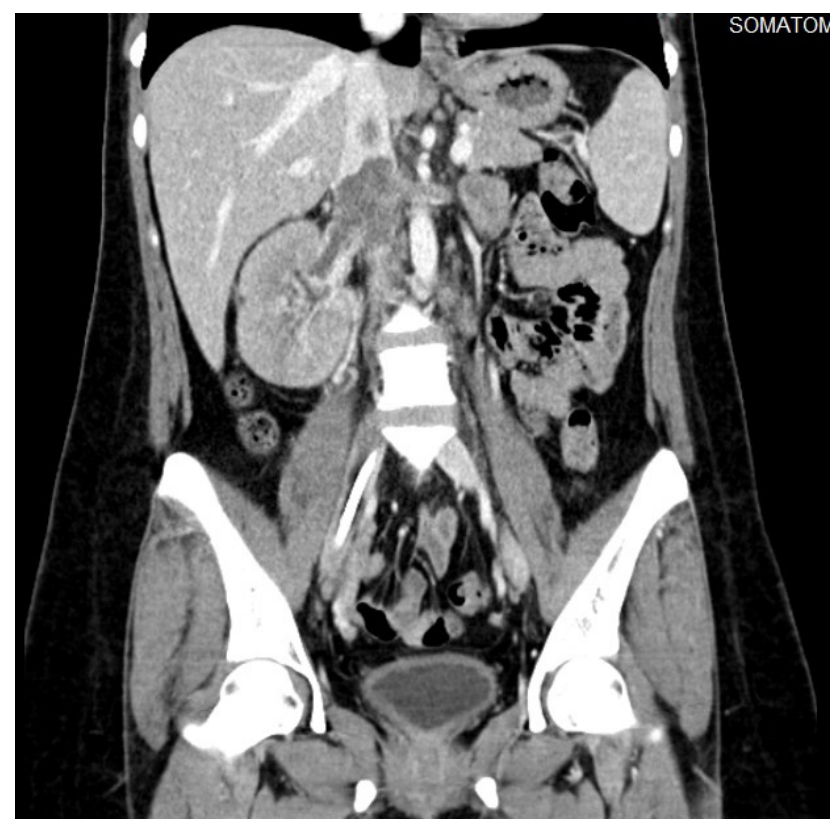

Despite the subacute characteristics of the clot, the patient was submitted to intravascular catheter-guided thrombolysis of the inferior vena cava with alteplase in a late attempt to recover renal function (30 days after onset), followed by 24 hours of infusion, with no adverse events. No clot was seen on 24-hour control venography (thus, thrombectomy was not indicated), and renal function improved progressively, with no need for dialysis.

After discharge, the improvement in kidney function was sustained with mycophenolate mofetil. Follow-up testing
Figure 2. Image suggestive of subcapsular areas of ischemia/ renal infarcts.

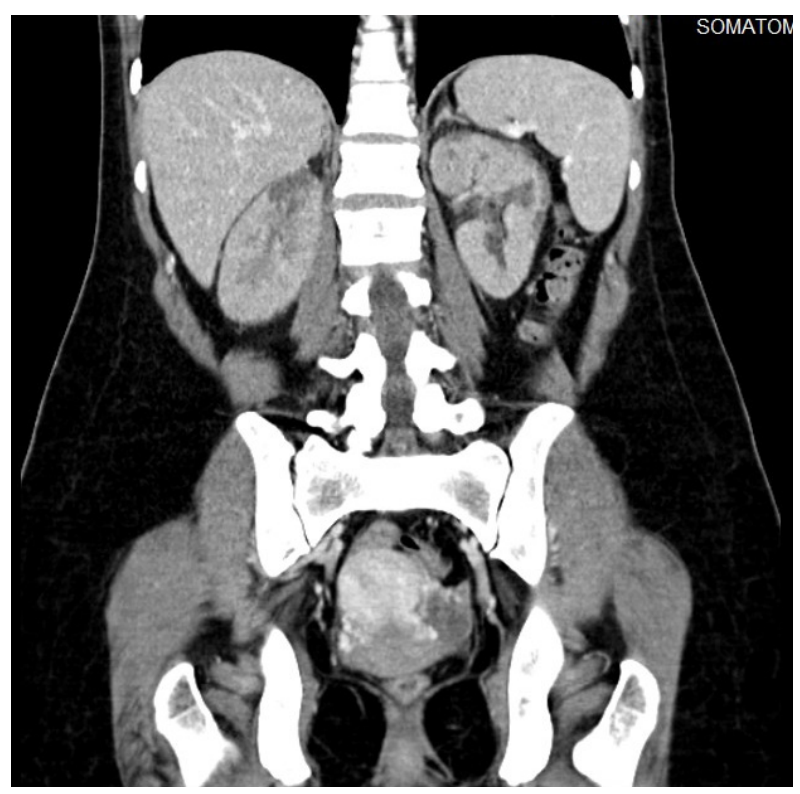

at 16 months yielded serum creatinine $1.0 \mathrm{mg} / \mathrm{dL}$, urea 27 $\mathrm{mg} / \mathrm{dL}$, and proteinuria $40.4 \mathrm{mg} / 24 \mathrm{~h}$. At 22 months, testing yielded serum creatinine $0.9 \mathrm{mg} / \mathrm{dL}(0.6-1.1)$, urea $29 \mathrm{mg} /$ $\mathrm{dL}$ (10-50), and proteinuria $49.32 \mathrm{mg} / 24 \mathrm{~h}$ (30-140). On Doppler US, the right renal artery, the renal veins and the inferior vena cava were within the normal range. In addition, the left kidney displayed signs of chronic nephropathy with poorly characterized arterial flow, possibly corresponding to hemodynamically significant stenosis (Figures 3, 4, 5 and 6). At present, the patient is followed in the out-patient setting.

Figure 3. Doppler US showing right renal artery flow.

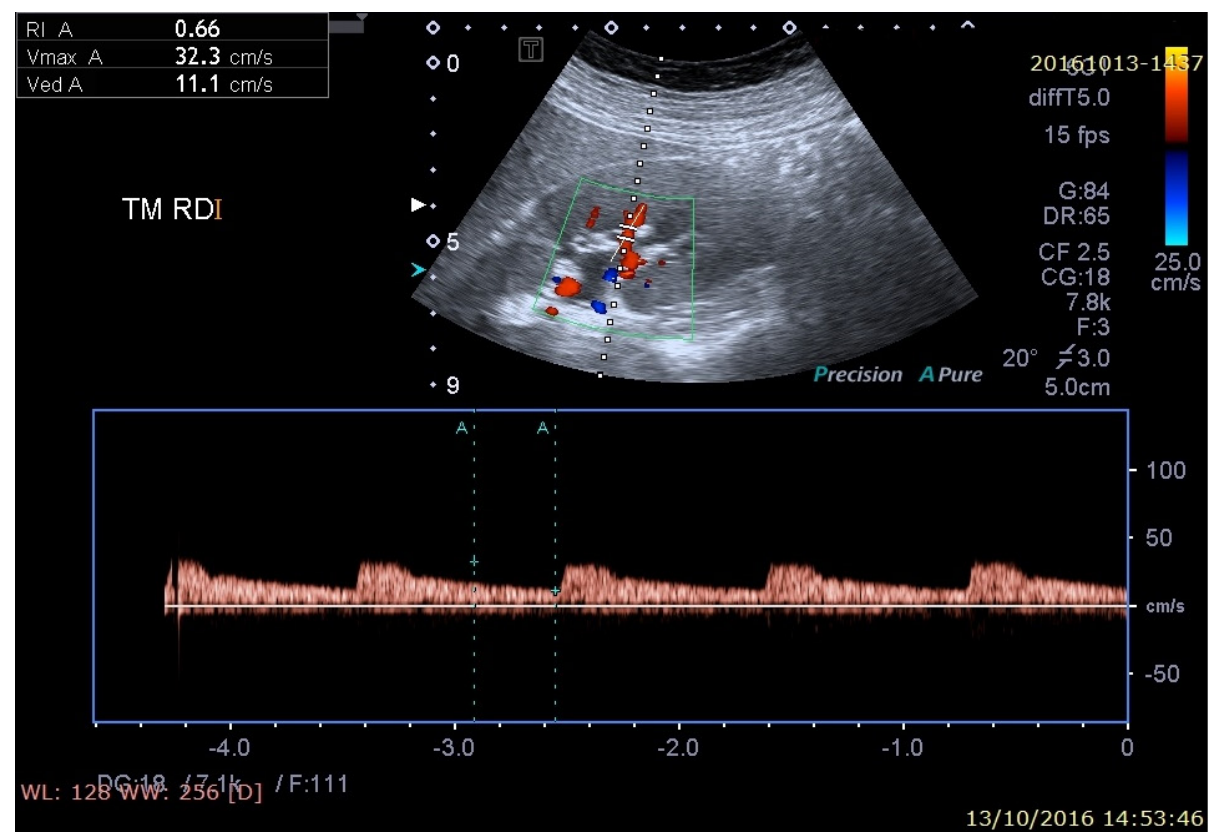


Figure 4. Doppler US showing left renal artery flow.

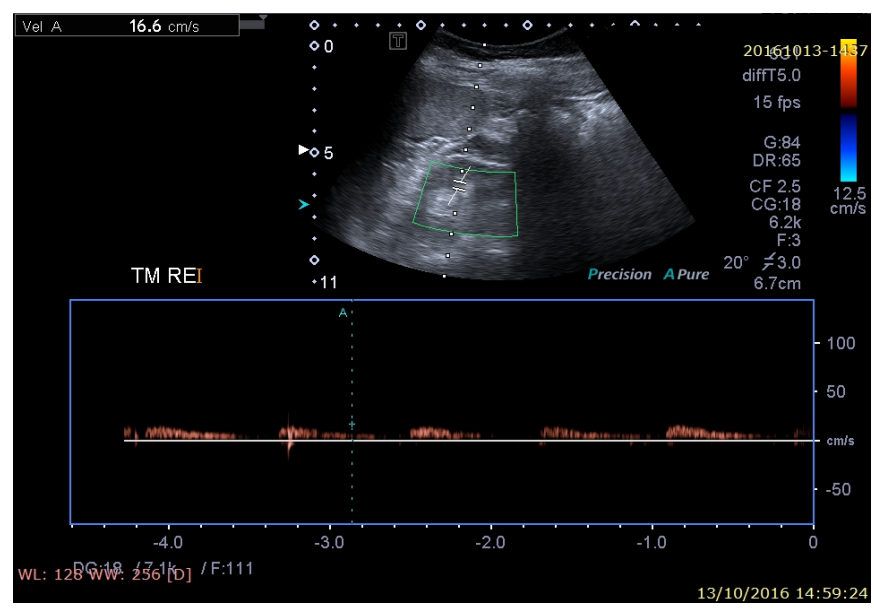

Figure 5. US of right kidney with preserved medullary cortical differentiation.

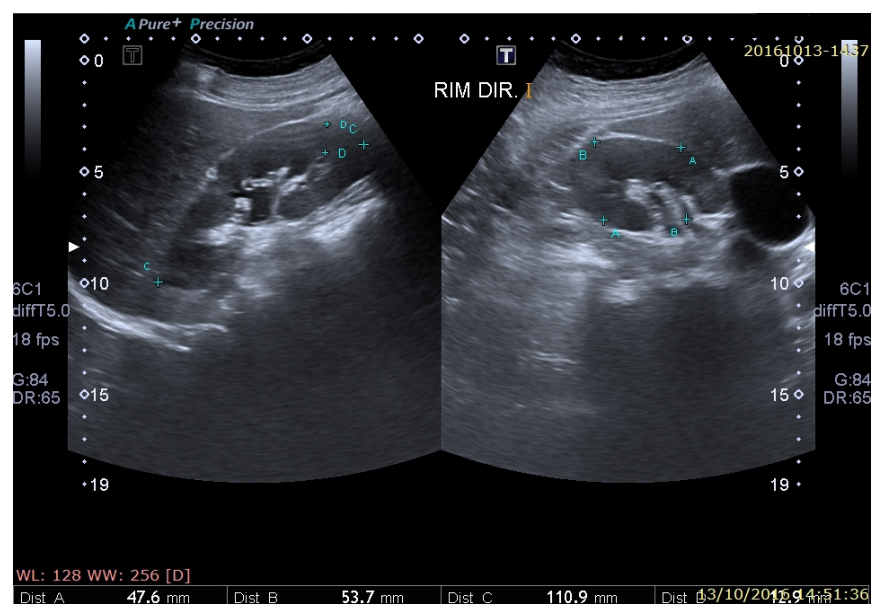

Figure 6. US of left kidney with loss of corticomedullary differentiation.

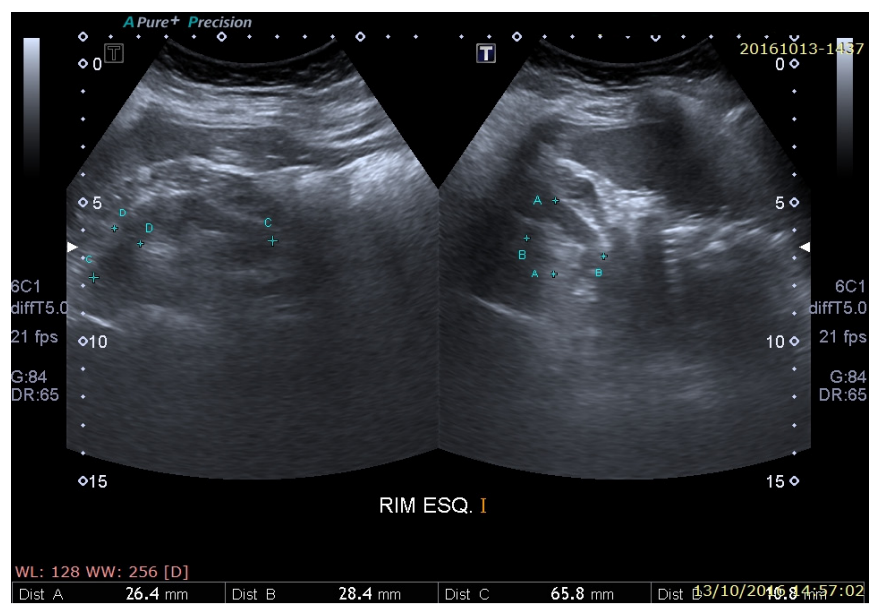

\section{DISCUSSION}

The risk of vein and arterial thrombosis depends on the etiology of NS but tends to be higher in patients with membranous nephropathy, focal segmental glomerulosclerosis and $\operatorname{IgA}$ nephropathy. ${ }^{7}$
Patients with membranous glomerulonephritis and SLE are at high risk for thromboembolism. In one study, 15 $(23 \%)$ of 66 patients with this condition had venous thromboembolism during an average follow-up period of 6.9 years. Factors other than NS can increase the incidence of thromboembolism in SLE patients, including antiphospholipid antibodies (aPLs). ${ }^{8}$

In patients with NS secondary to membranous nephropathy, hypoalbuminemia increases the risk of thrombosis, especially when albumin serum levels are below $2.8 \mathrm{mg} / \mathrm{dL} .{ }^{9}$

The prevalence of renal vein thrombosis in NS patients is $5-60 \%$. More specifically, studies have shown the prevalence to be $10-50 \%$ when NS is associated with minimal injury, membranoproliferative glomerulonephritis and focal segmental glomerulosclerosis, and $20-60 \%$ when associated with membranous nephropathy. ${ }^{2}$

The cause of hypercoagulability in NS patients is not well understood. Studies based on parameters of hemostasis activation, such as plasma levels of fibrinopeptide A (which is cleaved by thrombin in fibrinogen), have documented ongoing subclinical coagulation even in asymptomatic NS patients. Several hemostatic changes have been described, including decreased antithrombin III and plasminogen levels (through urinary loss), up regulation of platelet activation, hyperfibrinogenemia, inhibition of plasminogen activation, and circulating high-molecular-weight fibrinogen fragments. Hemoconcentration due to fluid loss is a complementary mechanism of vein thrombosis in patients with hypercoagulability. ${ }^{10}$

RVT is uncommon in outpatients without NS or history of malignancy. Additional causes include trauma (including renal biopsy), oral contraceptives and hypovolemia (especially in children). ${ }^{11}$ RVT may be bilateral or unilateral, affecting the left side twice as frequently as the right side, with possibility of gonadal vein thrombosis and pelvic congestion syndrome (women) or left testicle pain and varicocele (men), and involvement of the inferior vena cava. The condition is usually chronic, but acute forms occur with more dramatic manifestations. Onset tends to be insidious without kidney-related symptoms. In such patients, pulmonary embolism is usually the only clinical finding hinting at deep RVT. ${ }^{2}$

A rare complication, acute RVT is usually only associated with significant proteinuria in patients with underlying NS. However, it is associated with trauma, hypercoagulability and severe dehydration (especially in children), accompanied by flank pain, micro or macroscopic hematuria, raised LDH levels (without increased transaminase levels), enlarged kidneys, worsening of proteinuria and rapid loss of kidney function. Anemia and thrombocytopenia may also occur. ${ }^{1}$

Some authors have suggested chronic RVT in patients with underlying NS can lead to increased proteinuria or progressive renal impairment, but this has not been clearly demonstrated. ${ }^{12}$ 
In this scenario, glomerulonephritis is believed to be mediated by SLE immune complexes and by thrombotic microangiopathy associated with APS. The presence of aPLs increases the risk of thrombosis when associated with prothrombotic states (such as SLE), and an association between thrombosis and recent or current APS-related infections may be suspected. ${ }^{13}$ Lupus nephritis and nephropathy from APS can lead to hematuria, proteinuria, hypertension and kidney failure. Kidney biopsy is required to determine whether lupus nephritis is associated with or independent of nephropathy from APS. The latter is considered an independent risk factor for hypertension, increased creatinine levels and interstitial fibrosis in SLE patients. ${ }^{13}$

Image findings vary according to the rate of onset and the degree of vessel occlusion. Rapid-onset of RVT and complete occlusion lead to kidney enlargement in up to one week, followed by shrinkage and atrophy. Venography is the gold standard, but less invasive tests, such as Doppler US, computed angiotomography and NMRI, should be tried first. Doppler US shows kidney enlargement and hyperechogenicity in $90 \%$ of cases of early acute RVT. However, routine screening is not recommended in NS patients, even in those at high risk for RVT (protein excretion $>10 \mathrm{~g} /$ day, or serum albumin $<2.0 \mathrm{~g}$ / $\mathrm{dL}$ ). In fact, there is no evidence to support the benefit of an occult disease diagnosis, and a negative result does not rule out subsequent development of RVT. ${ }^{2}$

So far, no randomized trial has provided subsidies for optimizing treatment of RVT. The risk of RVT is higher in patients with membranous nephropathy, and studies have shown that reductions in serum albumin levels, rather than proteinuria, increases the risk of RVT in these patients, especially when levels drop below $2.8 \mathrm{~g} / \mathrm{dL}$, with a relative risk of 2.5. The risk doubles for each additional $1 \mathrm{~g} / \mathrm{dL}$ decrease. $^{2}$

Treatment for RVT involves two basic managements: prophylaxis against new thrombotic events (anticoagulation therapy) and clot dissolution (thrombolysis) or clot removal (thrombectomy). Early anticoagulation therapy can improve kidney function and reduce the risk of new thromboembolic events by dislodging or dissolving clots, but routine anticoagulation therapy has not been shown to be beneficial. In asymptomatic patients with unilateral RVT and NS, hypercoagulability can be partly reverted only by reducing proteinuria, administrating diuretics and/or statins and restricting salt and protein intake. Administration of angiotensin-converting enzyme inhibitors, angiotensin II receptor blockers, cyclosporine, mycophenolic acid and corticosteroids may also be required. ${ }^{6}$

Current guidelines recommend tailoring anticoagulation therapy, especially in patients with membranous nephropathy and very low serum albumin levels $(<2.0$ to $3.0 \mathrm{~g} / \mathrm{dL}$, depending on the risk of bleeding) and mild to moderate risk of bleeding, even in the absence of other indications, such as atrial fibrillation, hypercoagulability, surgery (abdominal, gynecological, orthopedic), heart failure, morbid obesity, prolonged immobilization and idiopathic thromboembolic events. The risk of bleeding can be estimated with scoring systems such as ATRIA and HAS-BLED. Anticoagulation therapy is not recommended for patients at high risk of bleeding. ${ }^{14}$

Anticoagulation may be induced with unfractioned or lowmolecular-weight heparin associated with warfarin. Direct thrombin inhibitors (dabigatran, argatroban) or direct factor Xa inhibitors (rivaroxaban, fondaparinux) are still considered the treatment of choice in this patient population. The target INR value is between 2 and 3. Warfarin may be used for 6-12 months, but some authors recommend using it as long as the patient remains nephrotic, and discontinuing it upon remission, unless indicated for other reasons. A vena cava filter is a relatively safe option when anticoagulation is contraindicated, such as in patients with pulmonary thromboembolism and documented RVT. ${ }^{1,6,15}$

Systemic fibrinolysis is generally not recommended for patients with RVT due to the increased risk of bleeding, especially intracranial hemorrhage, although some studies have reported success with local thrombolytic approaches (with or without thrombus extraction catheter) in nephrotic patients with acute RVT. Thus, in a series of 6 patients, renal venous flow was restored and serum creatinine levels decreased from 3.3 to $1.9 \mathrm{mg} / \mathrm{dL}$. After two years of followup, kidney function remained stable and no new RVT episodes had occurred. ${ }^{16}$

Surgical thrombectomy should be considered in patients with acute bilateral RVT and acute kidney failure who are not eligible for percutaneous thrombectomy and thrombolysis. ${ }^{6}$

A more radical measure, nephrectomy is indicated for patients with renal graft rupture, complete kidney necrosis with imminent rupture, and renal cell carcinoma with normal contralateral kidney. ${ }^{6}$

In the case reported here, acute kidney injury was most likely induced by RVT-related retrograde ischemia, possibly associated with thrombotic microangiopathy through a combination of factors (APS, NS and hypoalbuminemia), as suggested by the finding of right kidney ischemia without renal artery thrombosis on angiotomography. Lupus nephritis is another possible explanation, but a differential diagnosis according to the risk of bleeding would have required a kidney biopsy. Thus, while the observed kidney injury was likely caused by SLE-derived immune complexes, it should be kept in mind that no significant improvement in kidney function occurred after two courses of pulse therapy with methylprednisolone and cyclophosphamide. The dramatic response to thrombolysis (despite the fact that RVT was subacute) points to ischemic injury (nephropathy from APS) as the main mechanism of kidney failure.

\section{CONCLUSION}

The decision to treat RVT and the choice of approach should be tailored to each patient. A history of normal kidney function appears to be the main prognostic factor of favorable outcome. 
Local thrombolysis is recommended in acute RVT. Our case was submitted to thrombolysis for subacute RVT in an attempt to recover kidney function. The observed improvement of kidney function was sustained after thrombolysis and discontinuation of dialysis.

\section{REFERÊNCIAS}

1. Llach F. Hypercoagulability, renal vein thrombosis, and other thrombotic complications of nephrotic syndrome. Kidney Int. 1985;28(3):429-39.

2. Singhal R, Brimble KS. Thromboembolic complications in the nephrotic syndrome: pathophysiology and clinical management. Thromb Res. 2006;118(3):397-407.

3. Tarry WC, Moser AJ, Makhoul RG. Peripheral arterial thrombosis in the nephrotic syndrome. Surgery. 1993;114(3):618-23.

4. Parag KB, Somers SR, Seedat YK, Byrne S, Da Cruz CM, Kenoyer G. Arterial thrombosis in nephrotic syndrome. Am J Kidney Dis. 1990;15(2):176-7.

5. Mahmoodi BK, Kate MK, Waanders F. High absolute risk and predictors of venous and arterial thromboembolic events in patients with nephrotic syndrome: results from a large retrospective cohort study. J Vasc Surg. 2008;48(6):1633.

6. Asghar M, Ahmed K, Shah SS, Siddique MK, Dasgupta P, Khan MS. Renal Vein Thrombosis. Eur J Vasc Endovasc Surg. 2007;34(2):217-23.

7. Barbour SJ, Greenwald A, Djurdjev O, Levin A, Hladunewich MA, Nachman PH, et al. Disease-specific risk of venous thromboembolic events is increased in idiopathic glomerulonephritis. Kidney Int. 2012;81(2):190-5.

8. Mercadal L, du Montcel ST, Nochy D, Queffeulou G, Piette JC, Bagnis CI, Martinez F, et al. Factors affecting outcome and prognosis in membranous lupus nephropathy. Nephrol Dial Transplant. 2002;17(10):1771-8.

9. Lionaki S, Derebail VK, Hogan SL, Barbour S, Lee T,
The present case suggests that late thrombolysis may be an effective measure in selected patients with subacute RVT, especially those with APS and SLE.

Hladunewich M, et al. Venous thromboembolism in patients with membranous nephropathy. Clin J Am Soc Nephrol. 2012;7(1):4351.

10. Chen TY, Huang CC, Tsao CJ. Hemostatic molecular markers in nephrotic syndrome. American Journal of Hematology. 1993;44(4):276-9.

11. Wysokinski WE, Bierska IG, Greene EL, Grill D, Wiste H, McBaneII RD. Clinical characteristics and long-term followup of patients with renal vein thrombosis. Am J Kidney Dis. 2008;51(2):224-32.

12. Wagoner RD, Stanson AW, Holley KE, Winter CS. Renal vein thrombosis in idiopathic membranous glomerulopathy and nephrotic syndrome: Incidence and significance. Kidney Int. 1983;23(2):36874 .

13. Sciascia S, Baldovino S, Schreiber K, Solfietti L, Roccatello D. Antiphospholipid syndrome and the kidney. Semin Nephrol. 2015;35(5):478-86.

14. Fang MC, Go AS, Chang Y, Borowsky LH, Pomernacki NK, Udaltsova N, Singer DE. A new risk scheme to predict warfarinassociated hemorrhage: the ATRIA (Anticoagulation and Risk Factors in Atrial Fibrillation) study. J the Am Coll Cardiol. 2011;58(4):395401.

15. Glassock RJ. Prophylactic anticoagulation in nephrotic syndrome: a clinical conundrum. J Am Soc Nephrol. 2007;18(8):2221-5.

16. Kim HS, Fine DM, Atta MG. Catheter-directed thrombectomy and thrombolysis for acute renal vein thrombosis. J Vasc Interv Radiol. 2006;17(5):815-22.

\section{Como citar:}

Silva JV, Daher EF, Duarte PM, Linhares FA Filho, Zarate VC Júnior, Silva SL. Is late thrombolysis effective for subacute renal vein thrombosis in patients with nephrotic syndrome? a case report. Rev Med UFC. 2020 jul-set;60(3):52-57. 